\title{
ISOLATION AND IDENTIFICATION OF MYXOBACTERIA FROM SOILS AND PLANT MATERIALS, WITH SPECIAL REFERENCE TO DNA BASE COMPOSITION, QUINONE SYSTEM, AND CELLULAR FATTY ACID COM- POSITION, AND WITH A DESCRIPTION OF A NEW SPECIES, MYXOCOCCUS FLAVESCENS
}

\author{
SHIGERU YAMANAKA, AKIHIKO KAWAGUCHI,* AND KAZUO KOMAGATA** \\ Central Research Laboratories, Ajinomoto Co., Inc., \\ Kawasaki 210, Japan \\ * Department of Biology, The University of Tokyo, \\ Meguro-ku, Tokyo 153, Japan \\ ** Institute of Applied Microbiology, The University of Tokyo, \\ Bunkyo-ku, Tokyo 113, Japan
}

(Received March 2, 1987)

Myxobacteria were isolated in Japan from soils, decaying plant materials, and tree bark. The isolation methods we have used are the rabbit dung method, placing soil on bacterial smears, the filter paper method, and the agar medium method. Placing soil on bacterial smears was easy to manage. Addition of dealkaline lignin stimulated formation of welldifferentiated fruiting bodies on agar medium. This made it possible to investigate the morphology of fruiting bodies of myxobacteria on the agar medium in the laboratory. The myxobacteria isolated and purified were found to be strains of the genera Myxococcus and Archangium. Isolates were identified as Myxococcus stipitatus, Myxococcus fulvus, Myxococcus coralloides, and Archangium gephyra. A new species Myxococcus flavescens is proposed on the basis of morphological characteristics and production of diffusible light yellow pigment. All the tested strains gave positive reactions in catalase and urease. The DNA base composition of the myxobacteria examined ranged from 65 to $67 \mathrm{~mol} \%$ of guanine plus cytosine. The major quinone was menaquinone with 8 isoprenoid units (MK-8). The major cellular fatty acids were iso $15: 0$, iso $17: 0$, and $16: 1$.

Address reprint requests to: Mr. S. Yamanaka, Central Research Laboratories, Ajinomoto Co., Inc., 1-1, Suzuki-cho, Kawasaki-ku, Kawasaki 210, Japan. 
Myxobacteria are gram-negative and move by gliding. They form characteristic fruiting bodies and microcysts under certain conditions. They are widely distributed in nature in soils, animal dung, decaying plant materials, and tree bark. However, research on this group of bacteria has not been extensive. Conventional isolation methods do not apply, because the fruiting bodies form mostly on natural substrates. It is difficult to cultivate and produce fruiting bodies on ordinary media used in the laboratory. Some species have been recorded only in descriptions or photos. The number of strain named to date is small compared to other bacteria. Therefore, fundamental studies of the myxobacteria are rather limited in certain species, and are restricted to morphology.

In 1892 THAXTER (1) reported on the morphology and classification of the myxobacteria. MCCURDY (2-6) paid attention to the isolation and classification of this group of bacteria, and proposed a classification system based on the morphology of fruiting bodies and microcysts. MASUDA (7) published morphological study of fruiting bodies of a myxobacterium, and ABE et al.(8) reported isolation and purification methods and described their properties. However, little is known about the ecology of myxobacteria, and information about their physiology, biochemistry, chemotaxonomy, and phylogeny is limited. The practical importance of myxobacteria has not been fully determined. However, recent studies have shown this group of microorganisms to be useful sources for producing secondary metabolites (9-16).

This paper deals with the isolation of myxobacteria from soil, decaying plants, and tree bark; the formation of fruiting bodies in laboratory conditions; and the chemotaxonomy of these organisms.

\section{MATERIALS AND METHODS}

Isolation. Soil, decaying plant materials, and tree bark collected from forests, farms, riverside soil, and seaside soil in Yokohama and Kawasaki (Kanagawa, Japan) were the main isolation sources. Myxobacteria were isolated by the following four methods. Samples were incubated at $30^{\circ} \mathrm{C}$.

a. Rabbit dung method: The myxobacteria in soils were isolated as follows. Soil was placed in a Petri dish (approximately $80-100 \mathrm{~mm}$ in diameter) to a depth of $10-15 \mathrm{~mm}$, and moistened by spraying with sterile water. Rabbit dung was steamsterilized $\left(100^{\circ} \mathrm{C}, 10 \mathrm{~min}\right)$, immersed in a solution of actidione $(2.5 \mathrm{mg} / 100 \mathrm{ml})$ to sterilize molds instantly, then put on the soil (6-8 pieces/plate) (Fig. 1). After 1 week, fruiting bodies were investigated with a stereomicroscope, and pure cultures were obtained by the purification methods described below.

b. Placing soils on bacterial smears. Small quantities of soils or plant materials were placed on wet bacterial cells streaked on plain agar $(2 \%)$, and formation of fruiting bodies was investigated. Mostly the cells of Brevibacterium lactofermentum ATCC 13869 cultivated in nutrient broth were used, but these were replaceable with other bacterial cells. 


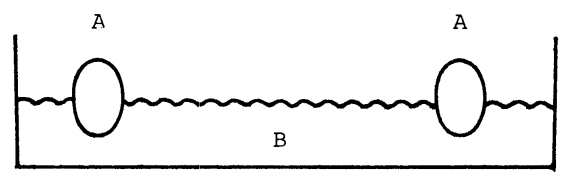

Fig. 1. Diagrammatic illustration of the method for isolation of myxobacteria (Rabbit dung method).

A: Rabbit dung (6-8 pieces/plate). Myxobacteria produce fruiting bodies on their surface. B: Soil.

Table 1. The composition of modified SP agar medium.

\begin{tabular}{lc}
\hline Medium component & Concentration $(\mathrm{g} / \mathrm{l})$ \\
\hline Bacterial cells & $3^{b}$ \\
$\quad$ or & $1^{c}$ \\
Yeast extract & 1 \\
Raffinose & 1 \\
Sucrose & 1 \\
Galactose & 5 \\
Soluble starch & 2.5 \\
Casitone & 0.5 \\
MgSO $_{4} \cdot 7 \mathrm{H}_{2} \mathrm{O}$ & 0.25 \\
$\mathrm{~K}_{2} \mathrm{HPO}_{4}$ & 15 \\
Agar & pH 7.4 with $\mathrm{NaOH}$ or $\mathrm{HCl}$ \\
\hline
\end{tabular}

a Cells of Brevibacterium lactofermentum ATCC 13869 cultivated in nutrient broth were used. The cells are replaceable with cells of other bacteria.

$b$ Wet weight.

c Dry weight.

c. Filter paper method. A piece of filter paper was placed on STANIER's agar medium(17). Soil or plant materials were put on it, and the formation of fruiting bodies was investigated.

d. Agar medium. Soils or plant materials were spread upon modified SP agar medium (2), the composition of which is shown in Table 1, and formation of fruiting bodies was investigated.

Purification. A small portion of fruiting bodies was scraped out with a platinum needle, and transferred onto modified SP agar medium. When a fruiting body was of the rigid type, it was transferred into a saline solution with glass beads (ca. $1 \mathrm{~mm}$ in diameter) in a test tube, and macerated with a mixer. The suspension thus obtained was plated on the modified SP agar medium. Inoculated plates were incubated at $30^{\circ} \mathrm{C}$ for about 1 week. The periphery of a swarm thus formed was scraped and transferred to another plate of the same agar medium. This process was repeated several times to obtain a fresh isolate in a pure culture. When a pure culture was obtained, the autoclaved cells of B. lactofermentum ATCC 13869 were 
replaced with $1 \mathrm{~g} / l$ of yeast extract in modified SP agar medium.

Observation of fruiting bodies. To develop fruiting bodies, a modified SP agar medium about $10 \mathrm{~mm}$ in depth was solidified in a Petri dish, and $2 \%$ agar with $0.4 \%$ dealkaline lignin (Tokyo Kasei Co., Tokyo, Japan; $\mathrm{pH} 7.4$ with $\mathrm{NaOH}$ or $\mathrm{HCl}$ ) was overlayered. The fruiting bodies developed on this double layered agar medium. The morphology of the fruiting bodies was observed after 6 to 10 days' incubation at $30^{\circ} \mathrm{C}$.

Identification methods. Myxobacterial strains were cultivated at $30^{\circ} \mathrm{C}$ on modified SP agar medium. Growth was investigated after 2 weeks. Fruiting bodies were studied with a stereomicroscope, and vegetative cells and microcysts with a phase-contrast microscope. Color of myxobacteria at various culture stages was determined mainly according to Methuen Handbook of Color(18). Gram staining was carried out by HUCKER and CONN's modification (19). Gliding motility was investigated by the growth on modified SP agar plate. The Congo red test (3) was done by flooding swarms with $0.01 \%$ aqueous solution of Congo red. Catalase activity was detected by the appearance of bubbles in a $3 \%$ hydrogen peroxide solution. Urease was determined on CHRISTENSEN's medium(20) after 3 weeks' incubation. Nitrate reduction was tested in $0.3 \%$ Casitone (Difco Laboratories, Detroit, Michigan, USA) broth ( $\mathrm{pH} 7.2$ ) containing $0.1 \% \mathrm{KNO}_{3}$ after 1,3 , and 7 days' incubation. Cellulose digestion was determined principally by the method described by ReICHENBACH and DwORKIN (21). Autoclaved $2 \%$ agar with $0.4 \%$ powdered cellulose (CC41, Whatman Chemical Separation Ltd., England) was poured on the surface of modified SP agar basal plates as a thin layer. Lysis zones were detected after 3 weeks' incubation. DNase test agar (Difco) was used for the hydrolysis of DNA. Hydrolysis of starch was determined with iodine solution on $0.3 \%$ Casitone (Difco) agar containing $0.2 \%$ soluble starch (pH 7.2) after 1, 2, and 3 weeks' incubation. Digestion of cells of a microorganism was determined by a method, essentially the same as for digesting cellulose, in which about $2.5 \%$ of autoclaved cells (on wet cell basis) of B. lactofermentum, Escherichia coli, and Saccharomyces cerevisiae, respectively, was used instead of cellulose.

Isolates were identified principally according to Bergey's Manual of Determinative Bacteriology, 8th edition (22).

DNA base composition. DNA was extracted by the method of MARMUR (23). DNA base composition was calculated from the thermal denaturation temperature $\left(T_{\mathrm{m}}\right)$ by the procedure of MARMUR and DOTY (24).

Quinone systems. Quinone systems were determined by the method of YAMADA et al. (25). To confirm the structure of quinones, we used mass spectrometry with a JEOL-JMSDX-300 (JEOL Ltd. Co., Tokyo, Japan), and ${ }^{1} \mathrm{H}$ NMR with a GX-400 (JEOL Ltd.).

Cellular fatty acid composition. To analyze cellular fatty acids, cells cultivated in Casitone liquid medium composed of Casitone (Difco) $20 \mathrm{~g} / \mathrm{l}$ and $\mathrm{MgSO}_{4} \cdot 7 \mathrm{H}_{2} \mathrm{O}$ $1 \mathrm{~g} / \mathrm{l}(\mathrm{pH} 7.2)$ at $30^{\circ} \mathrm{C}$ for 3 to 6 days with shaking were collected by centrifugation, dried in a desiccator, then analyzed for the acids. Methyl esters of the fatty acids 
were prepared with $5 \%$ anhydrous methanolic hydrochloride as described previously (26). The methyl esters were analyzed by gas-liquid chromatography using a glass column $(2 \mathrm{~m} \times 3 \mathrm{~mm})$ packed with $5 \%$ Shincrom E-71 on Shimalite (AW) (Shimadzu Co., Kyoto, Japan). Fatty acid pyrrolidides were prepared by treating the methyl esters of fatty acids with pyrrolidine and acetic acid, then applied to a glass column $(2 \mathrm{~m} \times 3 \mathrm{~mm})$ containing $5 \%$ Silar $10 \mathrm{C}$ on Chromosorb W (AMDMCS) (Shimadzu) (27). Methyl esters of the fatty acid pyrrolidides were also analyzed by GC-MS QP 1000 (Shimadzu). Analytical conditions were as described in previous papers $(26,27)$.

In the shorthand numbering system used to identify fatty acids, the figure preceding the colon indicates the number of carbon atoms in the fatty acid while that following the colon represents the number of double bonds present.

\section{RESULTS}

\section{Myxobacteria isolated and purified}

The results of isolation and purification of myxobacteria are presented in Table 2. Sources were natural situations such as forests, farms, riverside, and seaside. Myxobacteria were isolated and purified most readily by placing soil on bacterial smears. This procedure was easier than the rabbit dung method.

The three kinds of sources, soils, tree bark, and decaying plant materials, were amenable to isolation by the filter paper method, and this method helped in finding fruiting bodies because of the white background of the filter paper. The ratio of purified to observed strains by this method was lower than those of the dung and bacterial smear methods, probably because many of the fruiting bodies thus obtained were firm.

On the whole, fruiting bodies were observed in about $80 \%$ of the isolation sources. It was difficult to find a relationship between the type of purified strain and isolation method or isolation source.

Table 2. The result of isolation and purification of myxobacteria from natural sources.

\begin{tabular}{llcr}
\hline & & \multicolumn{2}{c}{ Number of myxobacteria } \\
\cline { 3 - 4 } Isolation method & Sources & Observed & Purified \\
\hline Rabbit dung method & Soils & 13 & 9 \\
Placing soils on & Soils & 77 & 39 \\
$\quad$ bacterial smears & Soils & 13 & 2 \\
Filter paper method & Barks of trees & 8 & 1 \\
& Decaying plants & 14 & 5 \\
Agar medium & Soils & 6 & 3 \\
& Decaying plants & 1 & 1 \\
Total & & 132 & 60 \\
\hline
\end{tabular}


Table 3. Morphology of

\begin{tabular}{|c|c|c|c|c|c|}
\hline \multirow[b]{2}{*}{$\begin{array}{l}\text { Isolation No. or } \\
\text { species designation }\end{array}$} & \multirow[b]{2}{*}{ Sources } & \multicolumn{4}{|c|}{ On modified SP agar medium } \\
\hline & & $\begin{array}{l}\text { Color of } \\
\text { swarm }\end{array}$ & $\begin{array}{l}\text { Color of } \\
\text { fruiting } \\
\text { body }^{c}\end{array}$ & Stalk & $\begin{array}{l}\text { Diffusible } \\
\text { pigment }\end{array}$ \\
\hline 2 & Farm soil & $\begin{array}{c}\text { Reddish } \\
\text { white }\end{array}$ & $\begin{array}{l}\text { Pastel } \\
\text { red }\end{array}$ & - & - \\
\hline 4 & Forest soil & $\begin{array}{l}\text { Reddish } \\
\text { white }\end{array}$ & $\begin{array}{l}\text { Pastel } \\
\text { red }\end{array}$ & - & - \\
\hline 5 & Forest soil & $\begin{array}{c}\text { Reddish } \\
\text { white }\end{array}$ & $\begin{array}{l}\text { Pastel } \\
\text { red }\end{array}$ & - & - \\
\hline 9 & Forest soil & $\begin{array}{l}\text { Light } \\
\text { yellow }\end{array}$ & $\begin{array}{l}\text { Deep } \\
\quad \text { yellow }\end{array}$ & - & $\begin{array}{l}\text { Light } \\
\text { yellow }\end{array}$ \\
\hline 18 & Forest soil & $\begin{array}{l}\text { Pale } \\
\text { red }\end{array}$ & $\begin{array}{l}\text { Reddish } \\
\text { orange }\end{array}$ & - & - \\
\hline 21 & Riverside soil & $\begin{array}{l}\text { Reddish } \\
\text { white }\end{array}$ & $\begin{array}{l}\text { Greyish } \\
\text { red }\end{array}$ & - & - \\
\hline 25 & Riverside soil & White & $\begin{array}{l}\text { Orange } \\
\text { white }\end{array}$ & - & - \\
\hline 27 & Riverside soil & $\begin{array}{c}\text { Reddish } \\
\text { white }\end{array}$ & $\begin{array}{l}\text { Orange } \\
\text { red }\end{array}$ & - & - \\
\hline 28 & Riverside soil & $\begin{array}{l}\text { Pale } \\
\text { red }\end{array}$ & $\begin{array}{l}\text { Pastel } \\
\text { red }\end{array}$ & - & - \\
\hline 29 & Seaside soil & $\begin{array}{l}\text { Reddish } \\
\text { white }\end{array}$ & $\begin{array}{l}\text { Greyish } \\
\text { ruby }\end{array}$ & - & - \\
\hline 30 & Seaside soil & $\begin{array}{l}\text { Pastel } \\
\text { red }\end{array}$ & $\begin{array}{l}\text { Reddish } \\
\cdot \text { orange }\end{array}$ & - & - \\
\hline 33 & Seaside soil & $\begin{array}{c}\text { Reddish } \\
\text { white }\end{array}$ & $\begin{array}{l}\text { Pastel } \\
\text { red }\end{array}$ & - & - \\
\hline 38 & Seaside soil & $\begin{array}{l}\text { Light } \\
\text { yellow }\end{array}$ & $\begin{array}{l}\text { Deep } \\
\text { yellow }\end{array}$ & - & $\begin{array}{l}\text { Light } \\
\text { yellow }\end{array}$ \\
\hline 40 & Riverside soil & $\begin{array}{l}\text { Pale } \\
\text { red }\end{array}$ & $\begin{array}{c}\text { Pastel } \\
\text { red }\end{array}$ & - & - \\
\hline 41 & Riverside soil & $\begin{array}{l}\text { Orange } \\
\text { white }\end{array}$ & $\begin{array}{l}\text { Pale } \\
\text { orange }\end{array}$ & - & - \\
\hline 44 & Riverside soil & $\begin{array}{c}\text { Reddish } \\
\text { white }\end{array}$ & $\begin{array}{l}\text { Pastel } \\
\text { red }\end{array}$ & - & - \\
\hline 50 & Forest soil & $\begin{array}{c}\text { Reddish } \\
\text { white }\end{array}$ & $\begin{array}{l}\text { Pastel } \\
\text { red }\end{array}$ & - & - \\
\hline 53 & $\begin{array}{l}\text { Plant material } \\
\text { of forest }\end{array}$ & $\begin{array}{l}\text { Light } \\
\text { yellow }\end{array}$ & $\begin{array}{l}\text { Deep } \\
\quad \text { orange }\end{array}$ & - & $\begin{array}{l}\text { Light } \\
\text { yellow }\end{array}$ \\
\hline 60 & $\begin{array}{l}\text { Plant material } \\
\text { of forest }\end{array}$ & $\begin{array}{l}\text { Pale } \\
\text { red }\end{array}$ & $\begin{array}{l}\text { Pastel } \\
\text { red }\end{array}$ & - & - \\
\hline 62 & Seaside soil & $\begin{array}{l}\text { Pale } \\
\text { yellow }\end{array}$ & $\begin{array}{l}\text { Reddish } \\
\text { yellow }\end{array}$ & - & $\begin{array}{l}\text { Light } \\
\text { yellow }\end{array}$ \\
\hline 63 & $\begin{array}{l}\text { Plant material } \\
\text { of forest }\end{array}$ & $\begin{array}{l}\text { Pale } \\
\text { yellow }\end{array}$ & $\begin{array}{l}\text { Reddish } \\
\text { yellow }\end{array}$ & - & $\begin{array}{l}\text { Light } \\
\text { yellow }\end{array}$ \\
\hline 64 & Seaside soil & $\begin{array}{l}\text { Reddish } \\
\text { white }\end{array}$ & $\begin{array}{l}\text { Orange } \\
\text { red }\end{array}$ & - & - \\
\hline
\end{tabular}


myxobacteria examined

\begin{tabular}{|c|c|c|c|c|}
\hline \multicolumn{2}{|c|}{ Microcyst } & \multicolumn{2}{|c|}{$\begin{array}{l}\text { On modified SP } \\
\text { agar }+\operatorname{lignin}^{a}\end{array}$} & \multirow{2}{*}{ Species identified } \\
\hline Shape $^{b}$ & Size $(\mu \mathrm{m})$ & $\begin{array}{l}\text { Color of } \\
\text { fruiting body }\end{array}$ & Stalk & \\
\hline$E$ to $S$ & $\begin{array}{c}1.2-1.4 \times \\
1.5-1.7\end{array}$ & $\begin{array}{l}\text { Pale } \\
\text { orange }\end{array}$ & - & Myxococcus fulvus \\
\hline $\mathrm{E}$ & $\begin{array}{c}1.1-1.2 \times \\
1.7-1.8\end{array}$ & $\begin{array}{l}\text { Light } \\
\text { yellow }\end{array}$ & - & Myxococcus fulvus \\
\hline $\mathrm{E}$ & $\begin{array}{c}1.1-1.2 \times \\
1.7-1.8\end{array}$ & $\begin{array}{l}\text { Light } \\
\text { orange }\end{array}$ & - & Myxococcus fulvus \\
\hline $\mathrm{E}$ & $1.8 \times 2.4$ & $\begin{array}{l}\text { Pale } \\
\quad \text { orange }\end{array}$ & - & Myxococcus flavescens sp. nov. \\
\hline $\mathrm{E}$ & $\begin{array}{l}1.2 \times \\
1.5-1.8\end{array}$ & $\begin{array}{l}\text { Reddish } \\
\text { orange }\end{array}$ & + & Myxococcus stipitatus \\
\hline $\mathrm{E}$ & $1.5 \times 1.8$ & $\begin{array}{l}\text { Reddish } \\
\text { orange }\end{array}$ & + & Myxococcus stipitatus \\
\hline$E$ to $S$ & $\begin{array}{l}1.2 \times \\
1.2-1.5\end{array}$ & $\begin{array}{l}\text { Pale } \\
\quad \text { orange }\end{array}$ & - & Myxococcus fulvus \\
\hline $\mathrm{E}$ & $\begin{array}{l}1.3-1.5 \times \\
1.8\end{array}$ & $\begin{array}{l}\text { Light } \\
\quad \text { orange }\end{array}$ & - & Myxococcus fulvus \\
\hline $\mathrm{E}$ & $0.9 \times 1.2$ & $\begin{array}{l}\text { Light } \\
\quad \text { orange }\end{array}$ & - & Myxococcus fulvus \\
\hline $\mathrm{E}$ & $1.1 \times 1.7$ & $\begin{array}{l}\text { Light } \\
\text { yellow }\end{array}$ & - & Myxococcus fulvus \\
\hline$E$ to $S$ & $\begin{array}{c}0.9-1.4 \times \\
1.1-1.6\end{array}$ & $\begin{array}{l}\text { Light } \\
\text { orange }\end{array}$ & - & Myxococcus fulvus \\
\hline $\mathrm{E}$ & $\begin{array}{c}1.1-1.3 \times \\
1.5-1.7\end{array}$ & $\begin{array}{l}\text { Pale } \\
\text { orange }\end{array}$ & - & Myxococcus fulvus \\
\hline $\mathrm{E}$ to $\mathrm{S}$ & $\begin{array}{c}1.6-1.8 \times \\
1.8-2.0\end{array}$ & $\begin{array}{l}\text { Pale } \\
\text { orange }\end{array}$ & - & Myxococcus flavescens sp. nov. \\
\hline$E$ to $S$ & $\begin{array}{c}1.3-1.5 \times \\
1.3-1.8\end{array}$ & - & - & Myxococcus fulvus \\
\hline $\mathrm{E}$ & $\begin{array}{c}1.2-1.3 \times \\
1.4-1.6\end{array}$ & White & - & Myxococcus fulvus \\
\hline $\mathrm{S}$ & $1.0-1.5$ & $\begin{array}{c}\text { Pastel } \\
\text { red }\end{array}$ & + & Myxococcus coralloides \\
\hline $\mathrm{E}$ & $\begin{array}{c}1.0-1.3 \times \\
1.4-1.8\end{array}$ & Orange & - & Myxococcus fulvus \\
\hline $\mathrm{S}$ & $2.5 \times 2.5$ & - & - & Myxococcus flavescens sp. nov. \\
\hline $\mathrm{E}$ & $\begin{array}{l}1.4 \times \\
1.6-1.9\end{array}$ & $\begin{array}{r}\text { Orange } \\
\text { white }\end{array}$ & - & Myxococcus fulvus \\
\hline $\mathrm{S}$ & $\begin{array}{c}1.5-1.9 \times \\
1.5-1.9\end{array}$ & - & - & Myxococcus flavescens sp. nov. \\
\hline $\mathrm{E}$ & $\begin{array}{l}1.8 \times \\
2.3-2.7\end{array}$ & $\begin{array}{l}\text { Light } \\
\text { yellow }\end{array}$ & - & Myxococcus flavescens sp. nov. \\
\hline $\mathrm{E}$ & $\begin{array}{c}1.0-1.3 \times \\
1.4-1.6\end{array}$ & $\begin{array}{l}\text { Light } \\
\text { yellow }\end{array}$ & - & Myxococcus fulvus \\
\hline
\end{tabular}


Table 3 .

\begin{tabular}{|c|c|c|c|c|c|}
\hline \multirow[b]{2}{*}{$\begin{array}{l}\text { Isolation No. or } \\
\text { species designation }\end{array}$} & \multirow[b]{2}{*}{ Sources } & \multicolumn{4}{|c|}{ On modified SP agar medium } \\
\hline & & $\begin{array}{l}\text { Color of } \\
\text { swarm }\end{array}$ & $\begin{array}{c}\text { Color of } \\
\text { fruiting } \\
\text { bodyc }^{c}\end{array}$ & Stalk & $\begin{array}{c}\text { Diffusible } \\
\text { pigment }\end{array}$ \\
\hline 65 & Seaside soil & $\begin{array}{l}\text { Pale } \\
\text { red }\end{array}$ & $\begin{array}{l}\text { Pastel } \\
\text { red }\end{array}$ & - & - \\
\hline 66 & Forest soil & $\begin{array}{l}\text { Pale } \\
\text { red }\end{array}$ & $\begin{array}{l}\text { Reddish } \\
\text { orange }\end{array}$ & - & $\begin{array}{l}\text { Light } \\
\text { yellow }\end{array}$ \\
\hline $\begin{array}{l}\text { Myxococcus coralloides } \\
\text { ATCC } 25202\end{array}$ & & $\begin{array}{l}\text { Light } \\
\quad \text { orange }\end{array}$ & Orange & - & - \\
\hline $\begin{array}{l}\text { Myxococcus fulvus } \\
\text { ATCC } 25199\end{array}$ & & $\begin{array}{l}\text { Pale } \\
\text { red }\end{array}$ & $\begin{array}{l}\text { Pastel } \\
\text { red }\end{array}$ & - & - \\
\hline $\begin{array}{l}\text { Myxococcus macrosporus } \\
\text { ATCC } 25619\end{array}$ & & $\begin{array}{l}\text { Reddish } \\
\text { white }\end{array}$ & $\begin{array}{c}\text { Pastel } \\
\text { red }\end{array}$ & - & - \\
\hline $\begin{array}{l}\text { Myxococcus stipitatus } \\
\text { ATCC } 29611\end{array}$ & & $\begin{array}{c}\text { Reddish } \\
\text { white }\end{array}$ & $\begin{array}{l}\text { Pale } \\
\text { red }\end{array}$ & - & - \\
\hline $\begin{array}{l}\text { Myxococcus virescens } \\
\text { ATCC } 25203\end{array}$ & & White & $\begin{array}{l}\text { Pale } \\
\quad \text { orange }\end{array}$ & - & - \\
\hline $\begin{array}{l}\text { Myxococcus xanthus } \\
\text { IFO } 13542\end{array}$ & & White & $\begin{array}{l}\text { Orange } \\
\text { white }\end{array}$ & - & - \\
\hline
\end{tabular}

Note: Morphology was examined after 6-10 days' cultivation at $30^{\circ} \mathrm{C}$.

a Dealkaline lignin (Tokyo Kasei, Co., Tokyo, Japan) at a concentration of $0.4 \%$ solidified with $2 \%$ agar was overlayered on modified SP agar.

The fruiting bodies observed in isolation media were orange, yellow, white, purple, or pink. The presence of stalks was clearly distinguishable. The purified strains were grown on modified SP agar medium, and the fruiting bodies so obtained seemed to be the rudimentary type $(2 l)$. The rudimentary fruiting bodies of 42 out of 60 strains had about the same color as the original fruiting bodies found on isolation media. Among the 60 purified strains, 16 had stalks on isolation medium but none formed stalks on the modified SP agar medium. Therefore, it was necessary to find an appropriate medium on which the original morphology of the fruiting bodies of the initial isolates could be investigated.

\section{General characteristics}

Of the 60 pure cultures, 24 strains were characterized. The vegetative cells of the majority had tapering ends. The microcysts were spherical or ellipsoidal. From these morphological aspects, most seemed to belong to the genus Myxococcus. Six strains in the genus Myхососсиs obtained from culture collections were used for comparison. A total of thirty strains were used to investigate morphology and chemotaxonomy.

We examined the morphology of fruiting bodies on modified SP agar medium, but it was impossible to obtain the same type of fruiting bodies as those on the 
(continued).

\begin{tabular}{|c|c|c|c|c|}
\hline \multicolumn{2}{|c|}{ Microcyst } & \multicolumn{2}{|c|}{ 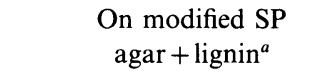 } & \multirow{2}{*}{ Species identified } \\
\hline Shape $^{b}$ & Size $(\mu \mathrm{m})$ & $\begin{array}{c}\text { Color of } \\
\text { fruiting body }\end{array}$ & Stalk & \\
\hline E to $R$ & $0.8 \times 1.8$ & $\begin{array}{l}\text { Reddish } \\
\text { orange }\end{array}$ & - & Archangium gephyra \\
\hline $\mathrm{E}$ & $\begin{array}{c}1.4-1.7 \times \\
1.9-2.7\end{array}$ & $\begin{array}{c}\text { Yellowish } \\
\text { white }\end{array}$ & - & Myxococcus flavescens sp. nov. \\
\hline- & - & - & - & \\
\hline- & - & - & - & \\
\hline$E$ to $S$ & $\begin{array}{c}1.4-2.0 \times \\
1.4-2.2\end{array}$ & - & - & \\
\hline $\mathrm{S}$ & $\begin{array}{c}1.3-1.5 \times \\
1.3-1.5\end{array}$ & - & - & \\
\hline $\mathrm{E}$ to $\mathrm{S}$ & $\begin{array}{c}1.5-2.5 \times \\
1.5-2.5\end{array}$ & - & - & \\
\hline$E$ to $S$ & $\begin{array}{c}1.5-1.75 \times \\
1.5-2.5\end{array}$ & - & - & \\
\hline
\end{tabular}

${ }^{b} \quad$ E, ellipsoidal; S, spherical; R, rod.

c Rudimentary fruiting body.

+ : formed, - : not formed.

isolation medium. As fruiting bodies were frequently found on tree bark in the isolation procedure, the lignin component was thought to be a factor for the fruiting body formation. Formation of fruiting bodies on tree bark was also found in photographs in a paper by MCCURDY (3). Therefore, modified SP agar medium with $0.4 \%$ dealkaline lignin as specified in MATERIALS AND METHODS was tested for fruiting body formation. The concentration of dealkaline lignin was the same as that of powdered cellulose for the digestion test. On this medium rudimentary fruiting bodies became more differentiated. With this technique, it was possible to obtain fruiting bodies on agar medium in most cases. The data for the fruiting bodies thus obtained are shown in Table 3, with other morphological data for swarm, rudimentary fruiting bodies, and microcysts. The morphology of the fruiting bodies on the medium with dealkaline lignin was not always the same as that on the isolation medium. However, the appearance of myxobacteria on dealkaline lignin medium was considered to represent their characteristics as pure culture.

The colors of fruiting bodies formed on modified SP agar medium with dealkaline lignin were essentially the same as those of rudimentary fruiting bodies on modified SP agar medium. Their size varied depending on culture conditions and culture phases, ranging from 60 to $600 \mu \mathrm{m}$ over all. The microcyst shape was 
Table 4. DNA base composition of myxobacteria.

\begin{tabular}{lcc}
\hline Microorganism (Isolation No.) & $T_{\mathrm{m}}\left({ }^{\circ} \mathrm{C}\right)$ & $\mathrm{G}+\mathrm{C}(\%)$ \\
\hline No. 2 & 96.3 & 65.7 \\
No. 18 & 96.0 & 65.1 \\
No. 38 & 96.8 & 67.1 \\
No. 44 & 96.3 & 65.7 \\
M. coralloides ATCC 25202 & & $68.1^{a}$ \\
M. virescence ATCC 25203 & & $67.6^{a}$ \\
\hline
\end{tabular}

a Cited from McCurdy and Wolf (28).

ellipsoidal, spherical, ellipsoidal to spherical, or rod, and the size seemed to be almost specific for strain groups (Table 3 ). The vegetative cells were slender rods $(0.5-0.9$ by $4-20 \mu \mathrm{m})$ with tapering ends, and they varied with the different culture conditions and culture phases. They grew at $\mathrm{pH} 6$ to 10 and at $37^{\circ} \mathrm{C}$ (maximum temperature). The vegetative cells had a gliding movement. The myxobacteria had a specific odor in common. A diffusible pigment was produced by some strains (Table 3).

All of the vegetative cells of myxobacteria examined were gram-negative. Swarms were stained with Congo red. They gave positive results in both catalase and urease. Nitrate was not reduced by any of strains except strain No. 65. They did not degrade cellulose but degraded casein, DNA, starch, and various kinds of cells of microorganisms, for example bacteria such as B. lactofermentum and $E$. coli and the yeast Saccharomyces cerevisiae.

Isolation sources are shown in Table 3.

The DNA base composition of distinctive strains are shown in Table 4 . The guanine plus cytosine $(\mathrm{G}+\mathrm{C})$ content in DNA ranged from 65.1 to $67.1 \%$, and the reported data are $68.1 \%$ for Myxococcus collaroides ATCC 25202 and $67.6 \%$ for Myxococcus virescens ATCC 25203.

All strains examined had menaquinone $8(\mathrm{MK}-8)$ as the major quinone.

The cellular fatty acid composition of these bacteria are shown in Table 5 . The major fatty acids were iso $15: 0$, iso $17: 0$, and $16: 1$. Also, iso $16: 0,14: 0,15: 0$, $16: 0$, and $17: 1$ were commonly detected. Acid 16:1 was identified as 9 -hexadecanoic acid (palmitoleic acid). Unsaturated fatty acid constituted $20.2-42.8 \%$ of the total acids. Branched fatty acid constituted $40.3-69.6 \%$ of the total acids.

\section{Identification of isolates}

From morphological, physiological, and chemotaxonomic characteristics, the isolates were identified as 5 species including a new species. Their characteristics are shown in Table 6, with data for reference strains. When sufficient information on reference strains was not available, the original descriptions are cited from the literature. The isolated strains were considered to belong to species of Myxococcus and Archangium. Figures 2 and 3 show the fruiting bodies and microcysts 


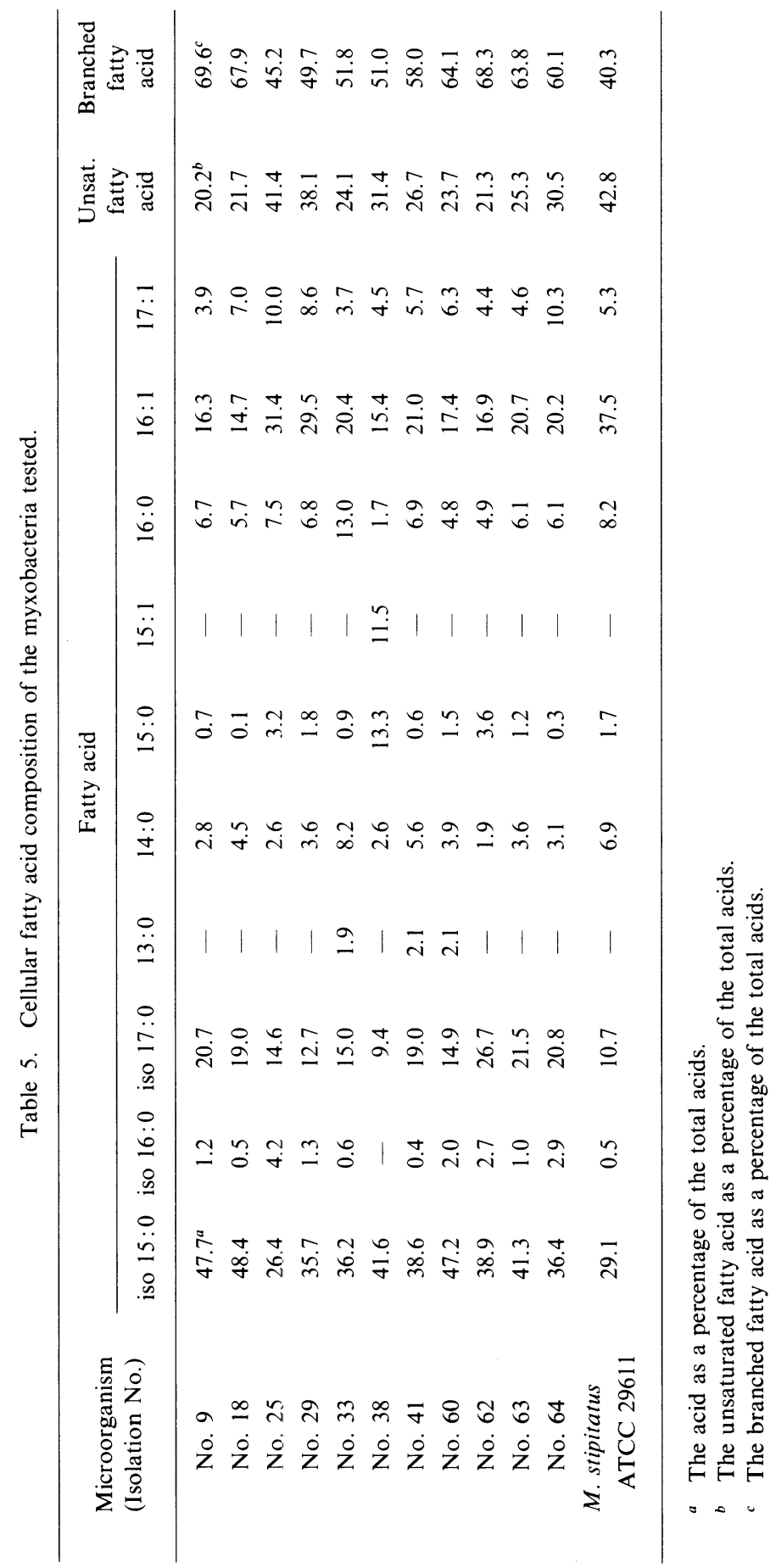


Table 6. Characteristics of species of

\begin{tabular}{|c|c|c|c|c|}
\hline & $\begin{array}{l}\text { Myxococcus } \\
\text { flavescens } \\
\text { (sp. nov., } \\
5 \text { isolates) }\end{array}$ & $\begin{array}{c}M . \text { virescens } \\
(1) \\
\text { (ATCC 25203) }\end{array}$ & $\begin{array}{c}\text { M. xanthus } \\
(29) \\
\text { (IFO 13542) }\end{array}$ & $\begin{array}{c}\text { M. macrosporus } \\
(30) \\
\text { (ATCC 29619) }\end{array}$ \\
\hline \multicolumn{5}{|l|}{$\begin{array}{l}\text { Fruiting bodies on modified SP } \\
\text { agar with dealkaline lignin }\end{array}$} \\
\hline Deliquescent & + & $(+)^{a}$ & $(+)^{a}$ & $(+)^{a}$ \\
\hline Raised on a stalk & - & - & - & - \\
\hline \multicolumn{5}{|l|}{ Microcysts } \\
\hline Ellipsoidal to spherical & + & + & + & + \\
\hline Ellipsoidal to rod & - & - & - & - \\
\hline $1.5 \mu \mathrm{m}$ or more in diameter & + & + & + & + \\
\hline Diffusible light yellow pigment & + & - & - & - \\
\hline Diffusible greenish pigment & - & $(+)^{b}$ & $(-)^{b}$ & $(-)^{b}$ \\
\hline Stained with Congo red & + & + & + & + \\
\hline Catalase & + & + & + & + \\
\hline Urease & + & + & + & + \\
\hline Nitrate reduction & - & - & - & - \\
\hline Cellulase & - & - & - & - \\
\hline Casein hydrolysis & + & + & + & + \\
\hline DNA hydrolysis & + & + & + & + \\
\hline Starch hydrolysis & + & + & + & + \\
\hline Degradation of microbial cells & + & + & + & + \\
\hline $\mathrm{G}+\mathrm{C} \mathrm{mol} \%$ & 67.1 & $(67.6)^{c}$ & & \\
\hline MK-8 & + & + & + & + \\
\hline \multirow{3}{*}{ Major cellular fatty acids } & iso $15: 0$ & & & \\
\hline & iso $17: 0$ & & & \\
\hline & $16: 1$ & & & \\
\hline
\end{tabular}

a Rudimentary fruiting bodies were formed on modified SP agar medium.

$b$ Cited from Bergey's Manual of Determinative Bacteriology (22).

of some typical isolated species. One group of myxobacteria produced diffusible light yellow pigment in agar. The formation of this pigment seemed to be stable. None of our isolates produced the diffusible green pigment of $M$. virescens, and this pigmentation is considered to be a key characteristic for identification in the genus Myxococcus (22). We consider our isolates to belong to a new species, and propose Myxococcus flavescens sp. nov. on the basis of this pigmentation although this species is morphologically similar to $M$. virescens. The characteristics of this new species are described as follows.

Myxococcus flavescens Yamanaka and Komagata sp. nov.

Strains: Isolate Nos. 9, 38, 53, 62, 63, and 66

Fruiting bodies on modified SP agar medium with dealkaline lignin are spherical to elongate, orange type, deliquescent, without stalks (Fig. 2-(1)). Produces diffusible light yellow pigment. 
Myrococcus and Archangium studied.

\begin{tabular}{|c|c|c|c|c|}
\hline & $\begin{array}{l}\text { M. stipitatus } \\
(31) \\
\text { (ATCC 29611, } \\
\text { and } 2 \text { isolates) }\end{array}$ & $\begin{array}{c}\text { M. fulvus } \\
\text { (ATCC 25199, } \\
\text { and } 4 \text { isolates) }\end{array}$ & $\begin{array}{l}\text { M. coralloides } \\
(1) \\
\text { (ATCC } 25202, \\
\text { and } 1 \text { isolate) }\end{array}$ & $\begin{array}{c}\text { Archangium } \\
\text { gephyra } \\
\text { (1 isolate) }\end{array}$ \\
\hline \multicolumn{5}{|l|}{$\begin{array}{c}\text { Fruiting bodies on modified SP } \\
\text { agar with dealkaline lignin }\end{array}$} \\
\hline Deliquescent & + & + & - & + \\
\hline Raised on a stalk & + & - & - & - \\
\hline \multicolumn{5}{|l|}{ Microcysts } \\
\hline Ellipsoidal to spherical & + & + & + & - \\
\hline Ellipsoidal to rod & - & - & - & + \\
\hline $1.5 \mu \mathrm{m}$ or more in diameter & - & - & - & \\
\hline Diffusible light yellow pigment & - & - & - & - \\
\hline Diffusible greenish pigment & - & - & - & - \\
\hline Stained with Congo red & + & + & + & + \\
\hline Catalase & + & + & + & + \\
\hline Urease & + & + & + & + \\
\hline Nitrate reduction & - & - & - & + \\
\hline Cellulase & - & - & - & - \\
\hline Casein hydrolysis & + & + & + & + \\
\hline DNA hydrolysis & + & + & + & + \\
\hline Starch hydrolysis & + & + & + & + \\
\hline Degradation of microbial cells & + & + & + & + \\
\hline $\mathrm{G}+\mathrm{C} \mathrm{mol} \%$ & 65.1 & 65.7 & $65.7(68.1)^{c}$ & \\
\hline $\mathrm{MK}-8$ & + & + & + & + \\
\hline \multirow[t]{3}{*}{ Major cellular fatty acids } & iso $15: 0$ & iso $15: 0$ & & \\
\hline & iso $17: 0$ & iso $17: 0$ & & \\
\hline & $16: 1$ & $16: 1$ & & \\
\hline
\end{tabular}

c Cited from MCCurdy and Wolf (28).

Microcysts are ellipsoidal to spherical, 1.5 to 2.5 by 1.5 to $2.5 \mu \mathrm{m}$ (Fig. 3-(1)). Vegetative cells are slender rods with tapering ends, gram negative, move by gliding. Grow at pH 6 to 10 . The maximum temperature is around $37^{\circ} \mathrm{C}$. Swarms are stained with Congo red.

Catalase and urease are produced. Nitrate is not reduced. Non-cellulolytic. Casein, starch, DNA are hydrolyzed. Bacterial and yeast cells are degradated. The $\mathrm{G}+\mathrm{C}$ content in DNA is $67.1 \%$ (type strain). Major quinone is MK-8 (type strain). Major cellular fatty acids are iso $15: 0$, iso $17: 0$, and $16: 1$.

Type strain: No. 38, isolated from seaside soil in Kanagawa in 1971.

The type strain has been deposited in the IAM Culture Collection, Institute of Applied Microbiology, The University of Tokyo, with accession number IAM 13189, and in the Japan Collection of Microorganisms (JCM) with accession number JCM 6245. 


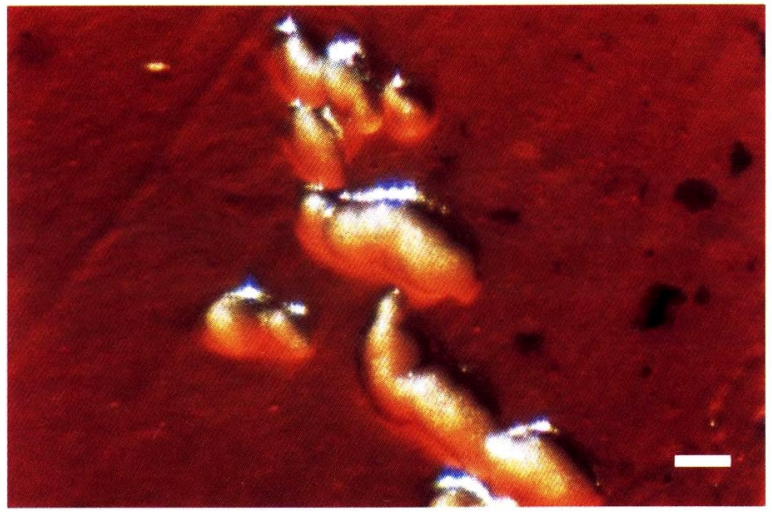

Fig. 2-(1). Myxococcus flavescence (Isolate No. 38), fruiting bodies on modified SP agar medium with dealkaline lignin. Bar, $100 \mu \mathrm{m}$.

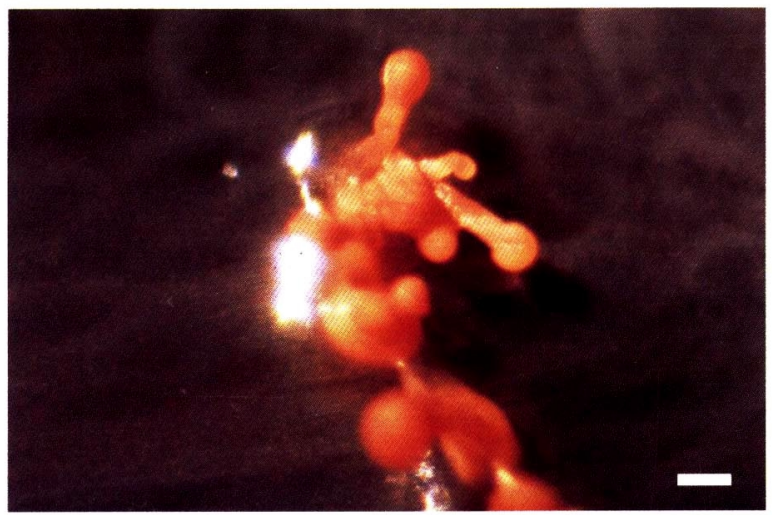

Fig. 2-(2). Myxococcus stipitatus (Isolate No. 18), fruiting bodies on modified SP agar medium with dealkaline lignin. Bar, $100 \mu \mathrm{m}$.

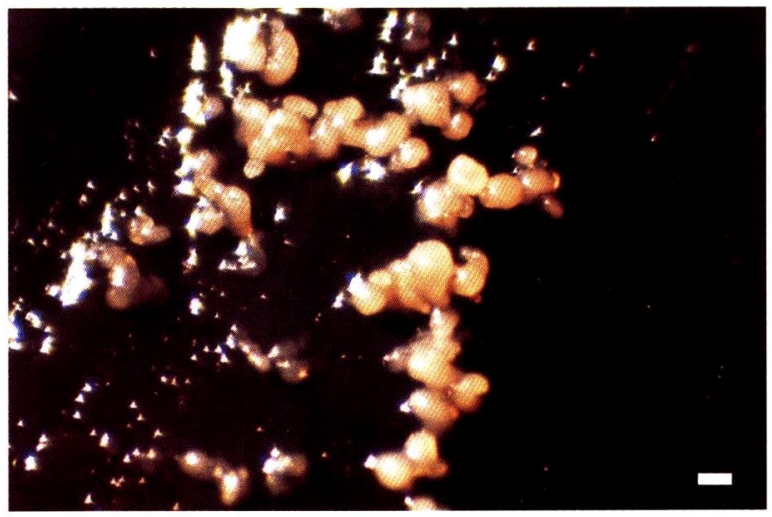

Fig. 2-(3). Myxococcus fulvus (Isolate No. 2), fruiting bodies on modified SP agar medium with dealkaline lignin. Bar, $100 \mu \mathrm{m}$. 


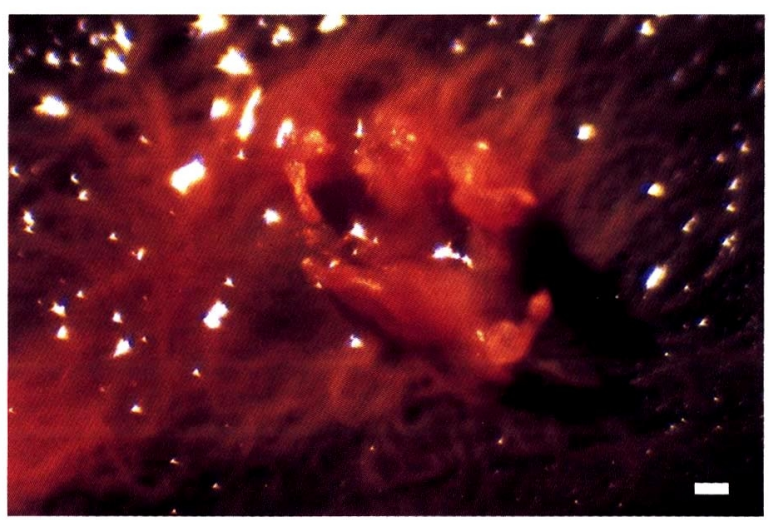

Fig. 2-(4). Myxococcus coralloides (Isolate No. 44), fruiting bodies on modified SP agar medium with dealkaline lignin. Bar, $100 \mu \mathrm{m}$.

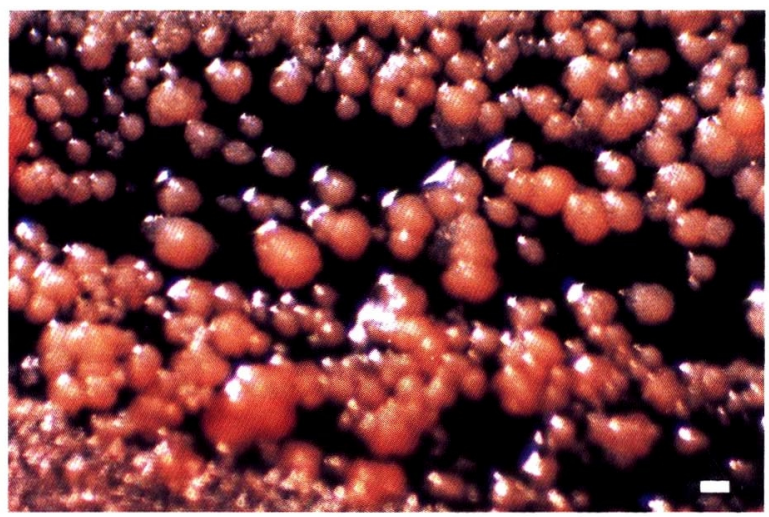

Fig. 2-(5). Archangium gephyra (Isolate No. 65), fruiting bodies on modified SP agar medium with dealkaline lignin. Bar, $100 \mu \mathrm{m}$.

\section{DISCUSSION}

Fruiting bodies formed on an isolation medium such as rabbit dung were considered difficult to reproduce on laboratory media used to grow myxobacteria. The addition of dealkaline lignin to modified SP agar medium proved to be effective in promoting formation of fruiting bodies on agar medium in the laboratory. This helped to identify fresh isolates as pure cultures. The actual effective component has not been determined yet. Strains obtained from culture collections did not produce fruiting bodies, even on this medium; it is not clear why. Thus, it was difficult to compare our fresh isolates with the types and the reference strains of the other species. So we could only refer to the published descriptions of the morphology of the known species. Stalk formation and distinction between the deliquesent and firm 


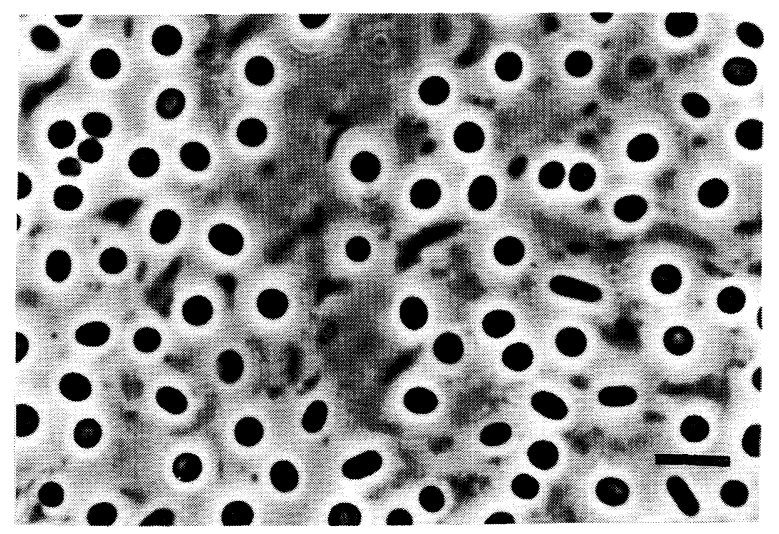

Fig. 3-(1). Myxococcus flavescens (Isolate No. 66), a phase contrast micrograph of microcysts. Bar, $5 \mu \mathrm{m}$.



Fig. 3-(2). Myxococcus fulvus (Isolate No. 2), a phase contrast micrograph of microcysts. Bar, $5 \mu \mathrm{m}$.

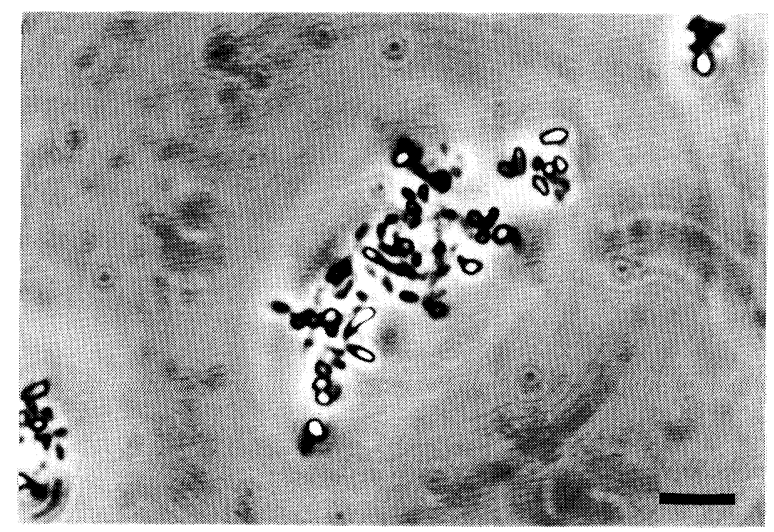

Fig. 3-(3). Archangium gephyra (Isolate No. 65), a phase contrast micrograph of microcysts. Bar, $5 \mu \mathrm{m}$. 
types appeared to be a reproducible characteristic in the laboratory. The phenotypic characteristics of fresh isolates should be described as accurately as possible using the medium containing dealkaline lignin as recommended above.

It was difficult to distinguish the forms of microcyst, whether ellipsoidal or spherical. It seems likely that the size is more important than shape for identification. In fact, it was possible to divide them into two groups; the larger microcysts were $1.5-2.5 \mu \mathrm{m}$ long, the smaller ones were $0.9-1.5$ wide by $1.1-1.9 \mu \mathrm{m}$ long.

The $\mathrm{G}+\mathrm{C}$ content in DNA was reported to be 67 to $71 \%$ for various myxobacteria $(22,28,32)$. The DNA base composition of the myxobacteria reported here fall within the above range.

KLEINIG et al. (33) suggested that the major quinone of $M$. fulvus was MK-8. Our data show that the major quinones of myxobacteria are MK-8.

SCHRÖDER and REICHENBACH (34) and WARE and DWORKIN (35) reported that the major cellular fatty acid composition of Stigmatella aurantiaca and Myxococcus xanthus, was iso $15: 0$, iso $17: 0$, and $16: 1$. This is mostly in line with our results. Hydroxy fatty acid was not detected under our analytical conditions. Since analysis of hydroxy fatty acid is useful for the classification of Pseudomonas species (36), more detailed analysis of this acid is necessary in the future.

Clearly the species of myxobacteria are chemotaxonomically homogeneous. So, we are forced to use morphological characteristics for classification and identification. An identification system for species in the genus Myxococcus, based on our results and on the citation of the descriptions in the literature, is proposed tentatively as follows:

I. Microcysts, $1.5-2.5$ by $1.5-2.5 \mu \mathrm{m}$.

A. Yellow fruiting bodies, green diffusible pigment produced. Myxococcus virescens Thaxter

B. Yellow to orange fruiting bodies, light yellow diffusible pigment produced.

M. flavescens Yamanaka and Komagata sp. nov.

C. Orange fruiting bodies, no yellow or green diffusible pigment produced M. xanthus Beebe

D. Yellow or brown fruiting bodies, no yellow or green diffusible pigment produced.

M. macrosporus (Krzemieniewska and Krzemieniewski) Zahler and McCurdy

II. Microcysts, $0.9-1.5$ by $1.1-1.9 \mu \mathrm{m}$.

A. Fruiting body deliquescent

A-1. Stalk formed.

M. stipitatus Thaxter

A-2. Stalk not formed.

M. fulvus Jahn 
B. Fruiting body firm.

M. coralloides Thaxter

Among myxobacteria, the strains of the genus Myxococcus are the most often isolated and studied in the world. There are more than half as many strains of Myxococcus stocked in culture collections as all other strains together. The present authors asked the culture collections listed in "World Directory of Collection of Culture of Microorganisms" (37) about the availability of Myxococcus. According to the answers, only 37 named strains of Myxococcus are now stocked in the 7 culture collections.

For a complete classification system it is necessary to collect more strains of myxobacteria from a wide variety of sources and apply the above methods to characterize them. And more detailed studies of the chemotaxonomic characteristics relative to the morphological characteristics are required for the better understanding of myxobacteria.

Authors are indebted to Drs. K. Yamada, H. Momose, H. Shibai, S. Miyashiro, K. Hirayama, and R. Tsugawa, of the Central Research Laboratories, Ajinomoto Co., Inc. for their helpful advice, and to Mr. H. Kano and Mr. I. Suzuki, Central Research Laboratories of Ajinomoto Co., Inc. for performing biochemical tests and maintaining microorganisms, respectively.

\section{REFERENCES}

1) R. ThaXter, Bot. Gaz., 17, 389 (1892).

2) H. D. McCurdy, Can. J. Microbiol., 9, 282 (1963).

3) H. D. McCurdy, Can. J. Microbiol., 15, 1453 (1969).

4) H. D. McCurdy, Int. J. Syst. Bacteriol., 20, 283 (1970).

5) H. D. McCurdy, Int. J. Syst. Bacteriol., 21, 40 (1971).

6) H. D. McCurdy, Int. J. Syst. Bacteriol., 21, 50 (1971).

7) S. Masuda, Nagaoa, 6, 44 (1959).

8) N. Abe, T. Watanabe, K. Izaki, and H. Takahashi, Nippon Biseibutsu Seitaigaku Kaiho, 1, 1 (1986).

9) S. M. Ringel, R. C. Greenough, S. Roemer, D. Connor, A. L. Gutt, B. Blair, G. Kanter, and M. von Strandtmann, J. Antibiot., 30, 371 (1977).

10) G. Thierbach and H. Reichenbach, Arch. Microbiol., 134, 104 (1983).

11) N. Onishi, K. Izaki, and H. Takahashi, J. Antibiot., 37, 13 (1984).

12) H. Irschik, R. Jansen, G. Höfle, K. Gerth, and H. Reichenbach, J. Antibiot., 38, 145 (1985).

13) W. Oettmeier, D. Godde, B. Kunze, and G. Höfle, Biochem. Biophys. Acta, 807, 216 (1985).

14) H. Irschik and H. Reichenbach, J. Antibiot., 38, 1237 (1985).

15) B. Kunze, W. Kohl, G. Höfle, and H. Reichenbach, J. Antibiot., 38, 1649 (1985).

16) R. Jansen, V. Wray, H. IrschiK, H. Reichenbach, and G. Höfle, Tetrahedron Lett., 26, 6031 (1985).

17) R. Y. StAniER, Bacteriol. Rev., 6, 143 (1942).

18) A. Kornerup and J. H. Wanscher, Methuen Handbook of Colour, Eyre Methuen, London (1981).

19) G. J. Hucker and H. J. Conn, Tech. Bull. N. Y. St. Agric. Exp. Sta., No. 93, 3 (1923).

20) W. B. Christensen, J. Bacteriol., 52, 461 (1946).

21) H. Reichenbach and M. Dworkin, In The Prokaryotes, Vol. I, ed. by M. P. Stark, H. Stolp, H. 
G. Trüper, A. Balows, and H. G. Schlegel, Springer-Verlag, Berlin, Heidelberg, and New York (1981), p. 328.

22) H. D. MCCurdy, In Bergey's Manual of Determinative Bacteriology, 8th ed., ed. by R. E. Buchanan and N. E. Gibbons, The Williams \& Wilkins Co., Baltimore (1974), p. 76.

23) J. Marmur, J. Mol. Biol., 3, 208 (1961).

24) J. Marmur and P. Doty, J. Mol. Biol., 5, 109 (1962).

$25)$ Y. Yamada, K. Aida, and T. Uemura, J. Gen. Appl. Microbiol., 15, 181 (1969).

26) K. Suzuki, K. Saito, A. Kawaguchi, S. Okuda, and K. Komagata, J. Gen. Appl. Microbiol., 27, 261 (1981).

27) A. Kawaguchi, Y. Kobayashi, Y. Ogawa, and S. OKuda, Chem. Pharm. Bull., 31, 3228 (1983).

28) H. D. MCCurdy and S. Wolf, Can. J. Microbiol., 13, 1707 (1967).

29) J. M. BEEBE, J. Bacteriol., 42, 193 (1941).

30) H. I. S. Krzemieniewscy, Acta Soc. Bot. Pol., 4, 1 (1926).

31) R. ThaXter, Bot. Gaz., 23, 395 (1897).

32) M. Mandel and E. R. Leadbetter, J. Bacteriol., 90, 1795 (1965).

33) H. Kleinig, H. Reichendach, N. Theobald, and H. Achenbach, Arch. Microbiol., 101, 91 (1974).

34) J. SChröDer and H. ReichenbaCh, Arch. Microbiol., 71, 384 (1970).

35 ) J. C. Ware and M. Dworkin, J. Bacteriol., 115, 253 (1973).

36) H. Oyaizu and K. Komagata, J. Gen. Appl. Microbiol., 29, 17 (1983).

37) S. M. Martin and V. B. D. SKerman, World Directory of Collections of Cultures of Microorganisms, Wiley-Interscience, New York, London, Sydney, and Toronto (1972). 